Article

\title{
Synthesis, Characterization, and Crystal Structure of a Triazine Anion Pentafluoroosmium(VI) Complex
}

\author{
Monther A. Khanfar ${ }^{1, *(1)}$, Basem F. Ali ${ }^{2,3}{ }^{(\mathbb{D})}$, Hashem Shorafa ${ }^{4}$ and Konrad Seppelt ${ }^{4}$ \\ 1 Department of Chemistry, The University of Jordan, Amman 11942, Jordan \\ 2 Department of Chemistry, King Faisal University, Al-Ahssa, Hufof 31982, Saudi Arabia; \\ bfali@kfu.edu.sa or bfali@aabu.edu.jo \\ 3 Department of Chemistry, Al al-Bayt University, Mafraq 25113, Jordan \\ 4 Institut für Chemie und Biochemie, Freie Universität Berlin, Fabeckstraße 34/36, 14195 Berlin, Germany; \\ shorafa@waldorfschule-darmstadt.de (H.S.); seppelt@zedat.fu-berlin.de (K.S.) \\ * Correspondence: m.khanfar@ju.edu.jo; Tel.: +962-6-5355-000
}

Received: 11 December 2017; Accepted: 23 January 2018; Published: 29 January 2018

\begin{abstract}
The synthesis and characterization of a novel triazine anion pentafluoroosmium(VI) complex are presented. The single crystal determination of the title compound (hereafter denoted $\mathbf{1}$ ) was carried out at $-140^{\circ} \mathrm{C}$. Compound $1, \mathrm{C}_{3} \mathrm{~F}_{4} \mathrm{~N}_{3} \mathrm{OsF}_{5}$, crystallizes in the monoclinic space group, $P 2{ }_{1} / n$, with unit cell dimensions: $a=8.6809(17) \AA, b=7.6848(15) \AA, c=12.415(3) \AA, \beta=102.633(4)^{\circ}$, $\mathrm{V}=808.2(3) \AA^{3}$, and $\mathrm{Z}=4$. Synthesis, characterization, $\mathrm{X}$-ray diffraction study along with the crystal supramolecular analysis of the title complex were carried out. The complex contains the anionic triazine unit $\mathrm{C}_{3} \mathrm{~N}_{3} \mathrm{~F}_{4}{ }^{-}$acting as a mono dentate ligand to osmium(VI) with five fluoro ligands in a slightly distorted octahedral geometry around osmium(VI) ion (osmium is denoted as Os). The $\mathrm{C}_{3} \mathrm{~N}_{3} \mathrm{~F}_{4}{ }^{-}$, triazine anion ring deviates from planarity, only with the $\mathrm{C} 1$ being tetrahedral. The crystal lattice of the title compound displays significant intermolecular X ...X interactions, namly $\mathrm{F} \cdots \mathrm{F}, \mathrm{F} \cdots \mathrm{N}$ and $\mathrm{F} \cdots \mathrm{C}$. All types of $\mathrm{X} \cdots \mathrm{X}$ bonding consolidate to form a three-dimensional network.
\end{abstract}

Keywords: triazine anion; crystal structure; fluoroosmium(VI) complexes; supramolecular crystal; $\mathrm{F} \cdots \mathrm{F} ; \mathrm{F} \cdots \mathrm{N} ; \mathrm{F} \cdots \mathrm{C}$ intermolecular interactions

\section{Introduction}

The employment of osmium(VI) fluoride/antimony(V) fluoride $\left(\mathrm{OsF}_{6} / \mathrm{SbF}_{5}\right)$ as a powerful oxidizing agent to break the aromaticity of benzene to form radical benzene cations was established some time ago [1]. This distorted radical cation was characterized using X-ray structural analysis [1]. However, the isolation of the benzene radical cation is a challenge. Seppelt and co-workers obtained the compounds $\mathrm{C}_{6} \mathrm{~F}_{6}{ }^{+} \mathrm{Os}_{2} \mathrm{~F}_{11}{ }^{-}$and $\mathrm{C}_{6} \mathrm{~F}_{6}{ }^{+} \mathrm{Sb}_{2} \mathrm{~F}_{11}{ }^{-}[1,2]$. The synthesis and crystal structure of other substituted benzene cations such as aniline radical cation [3] and radical cation of monocyclic arenes $[4,5]$ have also been reported. Further research was directed toward the formation of stable radicals for several organic systems [6-9]. On the other hand, fluorine-containing compounds are important for life and material sciences [10-12]. Fluorine is comparable to hydrogen atom in size but, possesses different physical and chemical properties, and capable of forming strong

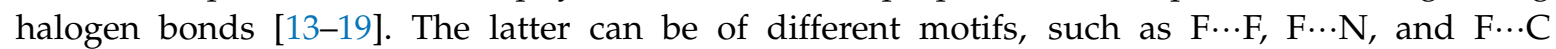
intermolecular interactions.

In an attempt to use other aromatic species in a manner similar to benzene, we encountered the 2,4,6-trifluoro-1,3,5-triazene ligand (Figure 1). It was expected that this system would proceed easily to form a radical cation compared to benzene, but a pentafluoroosmium(VI)-complex containing $\mathrm{C}_{3} \mathrm{~N}_{3} \mathrm{~F}_{4}{ }^{-}$ligand was detected instead. In this report, we are disclosing the successful synthesis, single crystal X-ray diffraction and crystal supramolecularity of this system. 
<smiles>Fc1nc(F)nc(F)n1</smiles>

Figure 1. The chemical structure of 2,4,6-trifluoro-1,3,5-triazene ligand.

\section{Materials and Methods}

The compound is unstable at room temperature and sensitive to moisture. Therefore, IR and UV spectra could not be recorded. Raman spectra showed strong fluorescence in all cases. Yield could only be estimated by the amount of colored crystalline material, often in mixtures of colorless crystals, which were possibly a starting material.

Caution: Handling $\mathrm{SbF}_{5}$ and $\mathrm{OsF}_{6}$ requires eye and skin protection.

The following reagents were purchased from the indicated vendor: $\mathrm{C}_{3} \mathrm{~N}_{3} \mathrm{~F}_{3}$ (Sigma-Aldrich Chemie $\mathrm{GmbH}$ ), $\mathrm{SbF}_{5}$ (Fluorochem Ltd.), $\mathrm{NH}_{4} \mathrm{~F}$ (E. Merck), $\mathrm{CF}_{3} \mathrm{COOH}$ (Merck Schuchardt). The triazine was checked by NMR spectroscopy for purity. The solvent sulfuryl fluoride chloride $\left(\mathrm{SO}_{2} \mathrm{ClF}\right)$ was prepared by treating a mixture of thionyl chloride $\left(\mathrm{SO}_{2} \mathrm{Cl}_{2}\right)$ and ammonium fluoride $\left(\mathrm{NH}_{4} \mathrm{~F}\right)$ with trifluoroacetic acid $\left(\mathrm{CF}_{3} \mathrm{COOH}\right)$ [20]. $\mathrm{SbF}_{5}$ was vacuum distilled twice using a glass vacuum line with $\mathrm{a}-30{ }^{\circ} \mathrm{C}$ trap. The resulting liquid was clear, colorless, and highly viscous. The compound $\mathrm{OsF}_{6}$ was obtained via a reaction of Os powder and $\mathrm{F}_{2}$ in Monel autoclaves at $300{ }^{\circ} \mathrm{C}$ [21]. Reagents and starting materials must be highly pure since contaminants are oxidized preferentially. Reactions were performed in PFA (Poly perfluorovinylether tetrafluoroethylene copolymer) tubes; volatile materials (anhydrous $\mathrm{SO}_{2} \mathrm{ClF}, \mathrm{OsF}_{6}$ ) were handled in a stainless-steel vacuum line.

$\mathrm{OsF}_{6}(100 \mathrm{mg})$ and $\mathrm{SO}_{2} \mathrm{ClF}(2 \mathrm{~mL})$ were condensed in a PFA tube containing $\mathrm{SbF}_{5}(50 \mathrm{mg})$. The mixture was allowed to warm to $0{ }^{\circ} \mathrm{C}$ to ensure a homogenous mixture. The mixture was cooled again with the aid of liquid nitrogen. $\mathrm{C}_{3} \mathrm{~N}_{3} \mathrm{~F}_{3}(100 \mathrm{mg})$ was condensed into the cooled mixture. The mixture was then allowed to warm very slowly to $-30{ }^{\circ} \mathrm{C}$, affording a yellow clear solution. At $-30{ }^{\circ} \mathrm{C}$, the excess $\mathrm{C}_{3} \mathrm{~N}_{3} \mathrm{~F}_{3}$ and other volatiles were removed under vacuum. After that, $\mathrm{SO}_{2} \mathrm{ClF}$ $\left(2 \mathrm{~mL}\right.$ ) was condensed in a PFA tube. Recrystallization from $-30{ }^{\circ} \mathrm{C}$ to $-78{ }^{\circ} \mathrm{C}$ afforded yellow crystals. Care must be taken to ensure that the temperature never exceeds $-30{ }^{\circ} \mathrm{C}$ throughout the entire procedure.

Single crystal for X-ray diffraction was performed on a Bruker-AXS, D8 venture, photon detector, tube: incotec microfokus (Mo K $\alpha$ radiation, Bruker, Germany) under oxygen- and moisture-free conditions at temperatures below $-100{ }^{\circ} \mathrm{C}$ using a special device of local design [22]. All data collections were performed at $-140{ }^{\circ} \mathrm{C}$. After semiempirical absorption corrections, the structure was solved by direct methods and refined using the program SHELXTL [23,24]. Non-hydrogen atoms were refined anisotropically; $\mathrm{H}$ atoms were refined isotropically. Relevant data collection and refinement parameters are listed in Table 1.

Crystallographic data in cif format have been deposited with the Cambridge Crystallographic Data Center (CCDC 1508189). Copies of the data can be obtained free of charge from The Director, CCDC, 12 Union Road, Cambridge, CB2 1EZ, UK, fax: +44 1223 366033, email: deposit@ccdc.cam.ac.uk or on the web at http:/ / www.ccdc.cam.ac.uk. 
Table 1. X-ray structure experimental details.

\begin{tabular}{|c|c|}
\hline CCDC Deposition Number & 1508189 \\
\hline Empirical formula; formula weight & $\mathrm{C}_{3} \mathrm{~F}_{4} \mathrm{~N}_{3} \mathrm{OsF}_{5} ; 439.26$ \\
\hline Temperature $(\mathrm{K})$ & $133(2)$ \\
\hline$\lambda(\AA)$ & 0.71073 \\
\hline Crystal system; space group & $\begin{array}{c}\text { Monoclinic; } P 2_{1} / n \\
\mathrm{a}=8.6809(17) \AA\end{array}$ \\
\hline Unit cell dimensions & $\begin{array}{c}\mathrm{b}=7.6848(15) \AA \\
\mathrm{c}=12.415(3) \AA \\
\beta=102.633(4)^{\circ}\end{array}$ \\
\hline $\mathrm{V}\left(\AA^{3}\right)$ & $808.2(3)$ \\
\hline Z & 4 \\
\hline $\mathrm{D}_{\text {calc. }}\left(\mathrm{Mg} / \mathrm{m}^{3}\right)$ & 3.610 \\
\hline Absorption coefficient $\left(\mathrm{mm}^{-1}\right)$ & 15.93 \\
\hline$F(000)$ & 781 \\
\hline Crystal size $\left(\mathrm{mm}^{3}\right)$ & $0.2 \times 0.1 \times 0.1$ \\
\hline Theta range for data collection & $2.6^{\circ}$ to $30.6^{\circ}$ \\
\hline Limiting indices & $-11 \leq \mathrm{h} \leq 12,-8 \leq \mathrm{k} \leq 10,-17 \leq 1 \leq 17$ \\
\hline Reflections collected & $1 \overline{2} 78 \overline{2}$ \\
\hline Completeness to theta $=25.125^{\circ}$ & $99.8 \%$ \\
\hline Independent reflections & $2474(\mathrm{R}(\mathrm{int})=0.023)$ \\
\hline Observed reflections & $2140(\mathrm{II}>2(\mathrm{I}))$ \\
\hline Reflections used for refinement & 2474 \\
\hline Refinement method & Full-matrix least-squares on $F^{2}$ \\
\hline Data/restraints/parameters & $2474 / 0 / 145$ \\
\hline Goodness-of-fit on $F^{2}$ & 1.052 \\
\hline$R$ values $(\mathrm{I}>2 \operatorname{sigma}(\mathrm{I}))$ & $\mathrm{R}_{1}=0.0152, \mathrm{wR}_{2}=0.0356$ \\
\hline$R$ values (all data) & $\mathrm{R}_{1}=0.0199, \mathrm{w} \mathrm{R}_{2}=0.0374$ \\
\hline Largest difference electron densities & 1.01 and $-1.01 \mathrm{e} \cdot \AA^{-3}$ \\
\hline
\end{tabular}

\section{Results and Discussion}

\subsection{Synthesis of 1}

The complex 1 was prepared as outlined in Scheme 1. The proposed complex formation mechanism involves the addition of a fluoride ion to a carbon center of $\mathrm{C}_{3} \mathrm{~N}_{3} \mathrm{~F}_{3}$, forming a $\mathrm{C}_{3} \mathrm{~N}_{3} \mathrm{~F}_{4}-$ anion, which in turn acts as a mono-dentate ligand to the metal center.<smiles>Fc1nc(F)nc(F)n1</smiles><smiles>CPC1=NC(F)(F)N(CCC(F)(F)F)C(F)=N1</smiles>

1

Scheme 1. Proposed stepwise formation of $\mathbf{1}$. 
The formation of the triazine anion was reported previously (Scheme 2) from the reaction of CsF and $\mathrm{C}_{3} \mathrm{~N}_{3} \mathrm{~F}_{3}$ without a sufficient characterization [25]. Kingston et al. [26] reported the synthesis of the same anion using a different strategy, and the product was characterized spectroscopically and by X-ray structural analysis. Therefore, our method represents a new strategy for the formation of this anion which forms the foundation for the synthesis of other anionic triazine species.

1.<smiles>Fc1nc(F)nc(F)n1</smiles>

2 .<smiles>CN(C)[Si](N(C)C)N(C)C</smiles>

Scheme 2. Reported methods for the preparation of $\mathrm{C}_{3} \mathrm{~N}_{3} \mathrm{~F}_{4}{ }^{-}$. Reaction 1, Reference [25]; reaction 2, Reference [26].

\subsection{Molecular Structure}

The asymmetric unit in 1 contains one independent complex (Figure 2). The molecular complex has octahedral geometry around an osmium atom. The unique M-F distances are 1.8638(17)-1.8696(17) $\AA$, while the linear and perpendicular F-Os-F angles are in the ranges of 179.25(8)-178.68(7) and $87.78(8)-91.55(8)^{\circ}$ (Table 2). These bond distances and angles are within the reported values of $\mathrm{M}-\mathrm{F}-$ containing compounds $[2,27,28]$. The $\mathrm{C} 3 / \mathrm{N} 3$ part of the $\mathrm{C}_{3} \mathrm{~N}_{3} \mathrm{~F}_{4}{ }^{-}$ring is planar, only with the $\mathrm{C} 1$ atom being tetrahedral. The $\mathrm{C}-\mathrm{N}$ distances in the ranges of 1.305(4)-1.320(4) and 1.445(4)-1.422(4) are consistent with the bonds between double $\mathrm{C}=\mathrm{N}$ and single $\mathrm{C}-\mathrm{N}$ bonds, indicating a delocalization of charge in the ring consistent with the anion geometry. This is best described by the resonance shown in Figure 3. These $\mathrm{C}-\mathrm{N}$ bond distances and angles are slightly different compared to those of the free anionic $\mathrm{C}_{3} \mathrm{~N}_{3} \mathrm{~F}_{4}{ }^{-}$[26]. The difference in some distances of $\mathrm{C}-\mathrm{N}$ and $\mathrm{C}-\mathrm{F}$ bonds, shown in Table 2, might be attributed to the fact that the reported anion [26] is a free anion crystallized with another counter cation which allows the complete delocalization of the charge over the anion, while the anion in the title compound is bonded through one $\mathrm{N}$ atom with $\mathrm{Os}(\mathrm{VI})$ and consequently affects the delocalization of the charge over the anion. This is also evident by the different planarity of the reported anion $\mathrm{C}_{3} \mathrm{~N}_{3} \mathrm{~F}_{4}{ }^{-}$ring as compared to the bonded one (this work). The $\mathrm{C}-\mathrm{F}$ bond distances are different depending on the center to which they bonded. Those bonded to the tetrahedral $\mathrm{C} 1$ are longer than those bonded to the planar $s p^{2}$ carbons (C2 and C3; Table 2). This fact makes this anion susceptible to selective substitution (weak C1-F bonds), and this has been used to synthesize the substituted triazine anions [26]. 


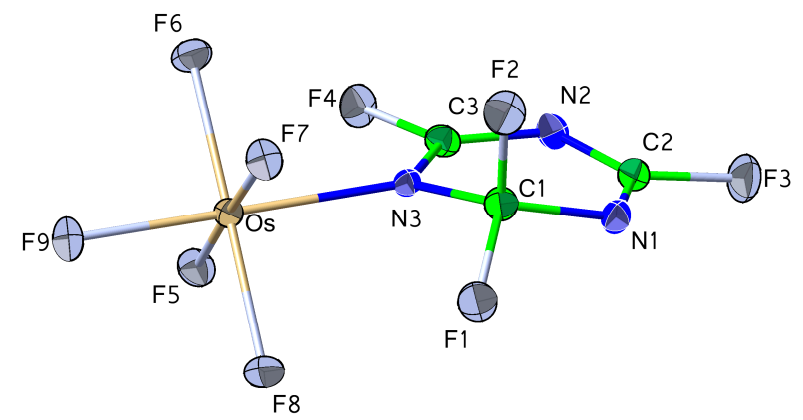

Figure 2. Molecular geometry of complex 1 with atom labeling scheme. Atoms drawn at the 50\% probability level.<smiles>CC(C)C1=NC(F)(F)NC(F)=N1</smiles>

Figure 3. Charge delocalization in $\mathrm{C}_{3} \mathrm{~N}_{3} \mathrm{~F}_{4}{ }^{-}$anion.

Table 2. Selected bond lengths $(\AA)$, bond and angles $\left(^{\circ}\right)$ in $\mathbf{1}$.

\begin{tabular}{|c|c|c|}
\hline Bond Distances & Os-F Complex a & Os-F average Complex \\
\hline \multirow{5}{*}{ Os-F } & $1.8696(17)$ & \\
\hline & 1.8661(17) & \\
\hline & $1.8638(17)$ & $1.825^{\mathrm{b}} ; 1.857^{\mathrm{c}}$ \\
\hline & $1.8687(17)$ & \\
\hline & $1.8686(17)$ & \\
\hline \multirow[t]{2}{*}{ Os-N3 } & $2.078(2)^{a}$ & \\
\hline & $\mathrm{C}_{3} \mathrm{~N}_{3} \mathrm{~F}_{4}-$ anion $^{\mathrm{a}}$ & $\mathrm{C}_{3} \mathrm{~N}_{3} \mathrm{~F}_{4}{ }^{-}$anion ${ }^{\mathrm{d}}$ \\
\hline C1-F1 & $1.332(3)$ & $1.400(4)$ \\
\hline $\mathrm{C} 1-\mathrm{F} 2$ & $1.351(3)$ & $1.383(4)$ \\
\hline $\mathrm{C} 1-\mathrm{N} 1$ & $1.422(4)$ & $1.403(4)$ \\
\hline C1-N3 & $1.445(4)$ & $1.400(4)$ \\
\hline $\mathrm{N} 1-\mathrm{C} 2$ & $1.316(4)$ & $1.277(4)$ \\
\hline N2-C3 & $1.319(4)$ & $1.319(4)$ \\
\hline N3-C3 & $1.320(4)$ & $1.279(4)$ \\
\hline $\mathrm{C} 2-\mathrm{N} 2$ & $1.305(4)$ & $1.329(4)$ \\
\hline C2-F3 & $1.297(3)$ & $1.345(3)$ \\
\hline C3-F4 & $1.298(3)$ & $1.348(3)$ \\
\hline $\mathrm{N} 1-\mathrm{C} 1-\mathrm{N} 3$ & $112.8(2)$ & $120.4(3)$ \\
\hline $\mathrm{N} 1-\mathrm{C} 2-\mathrm{N} 2$ & $126.7(3)$ & $132.0(3)$ \\
\hline $\mathrm{F} 4-\mathrm{C} 3-\mathrm{N} 2$ & $115.3(2)$ & $113.3(3)$ \\
\hline N2-C3-N3 & $128.9(3)$ & 132.2(3) \\
\hline F4-C3-N3 & $115.8(2)$ & $114.4(3)$ \\
\hline $\mathrm{F} 1-\mathrm{C} 1-\mathrm{F} 2$ & $105.3(2)$ & $101.1(2)$ \\
\hline
\end{tabular}

\subsection{Crystal Packing}

The crystal packing involves extensive halogen ...halogen interactions. These interactions assemble the molecular complexes into a supramolecular three-dimensional lattice [29], as shown in Figure 4,

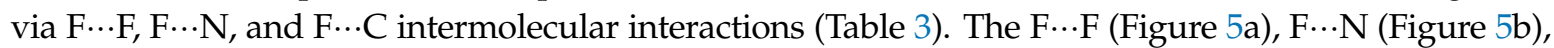
and F...C (Figure 5c) interactions are in the ranges of 2.834-2.887, 2.771-2.970, and 2.770-2.771 $\AA$, respectively. 


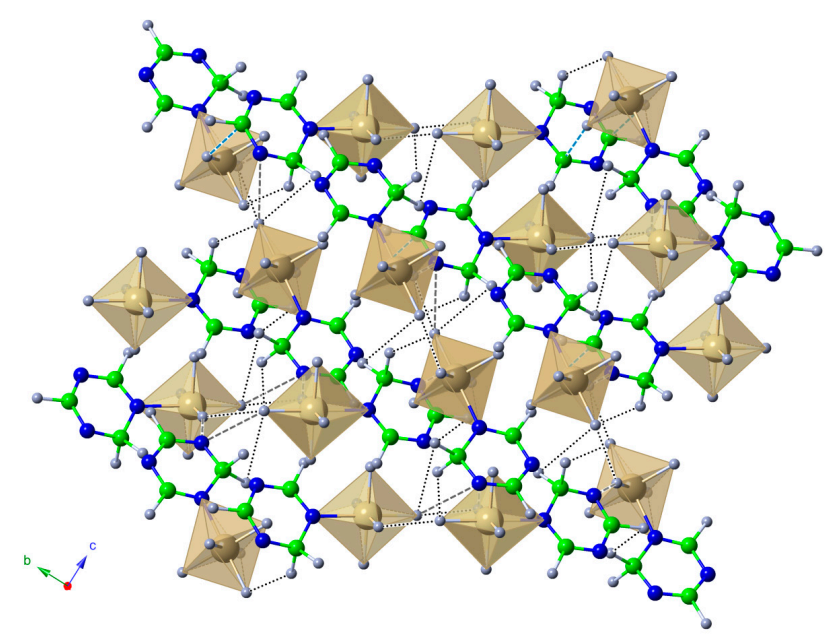

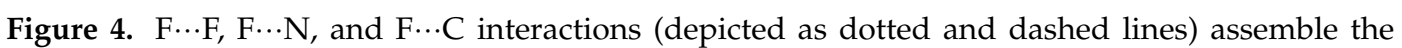
molecular complexes into a supramolecular three-dimensional network.

Table 3. Halogen bond geometry $\left(\AA,^{\circ}\right)$.

\begin{tabular}{|c|c|c|}
\hline $\mathrm{F} \cdots \mathrm{F}$ interactions & $F \cdots F$ & $-F \cdots X-$ \\
\hline 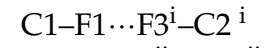 & 2.834 & 87,114 \\
\hline 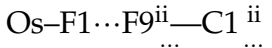 & 2.840 & 88,106 \\
\hline Os-F9...F2 ${ }^{\text {iii_-C1 }}$ iii & 2.873 & 143,102 \\
\hline Os-F8 $\cdots F 9^{i v}-O s$ iv & 2.887 & 130,137 \\
\hline $\mathrm{F} \cdots \mathrm{N}$ interactions & $\mathrm{F} \cdots \mathrm{N}$ & $-\mathrm{F} \cdots \mathrm{N}$ \\
\hline Os-F9 $\cdots \mathrm{N} 1^{\mathrm{v}}$ & 2.771 & 153 \\
\hline Os-F8 $\cdots \mathrm{N} 1^{\mathrm{i}}$ & 2.857 & 165 \\
\hline F...C interactions & $\mathrm{F} \cdots \mathrm{C}$ & $-F \cdots C-$ \\
\hline Os-F7...C3 ${ }^{\text {iii }}$ & 2.770 & 139,91 \\
\hline Os-F6‥C2 ${ }^{\mathrm{iii}}$ & 2.771 & 128,84 \\
\hline
\end{tabular}

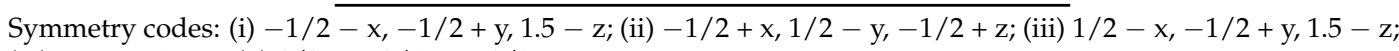
(iv) $-\mathrm{x},-\mathrm{y}, 2-\mathrm{z}$; (v) $1 / 2+\mathrm{x}, 1 / 2-\mathrm{y}, 1 / 2+\mathrm{z}$.

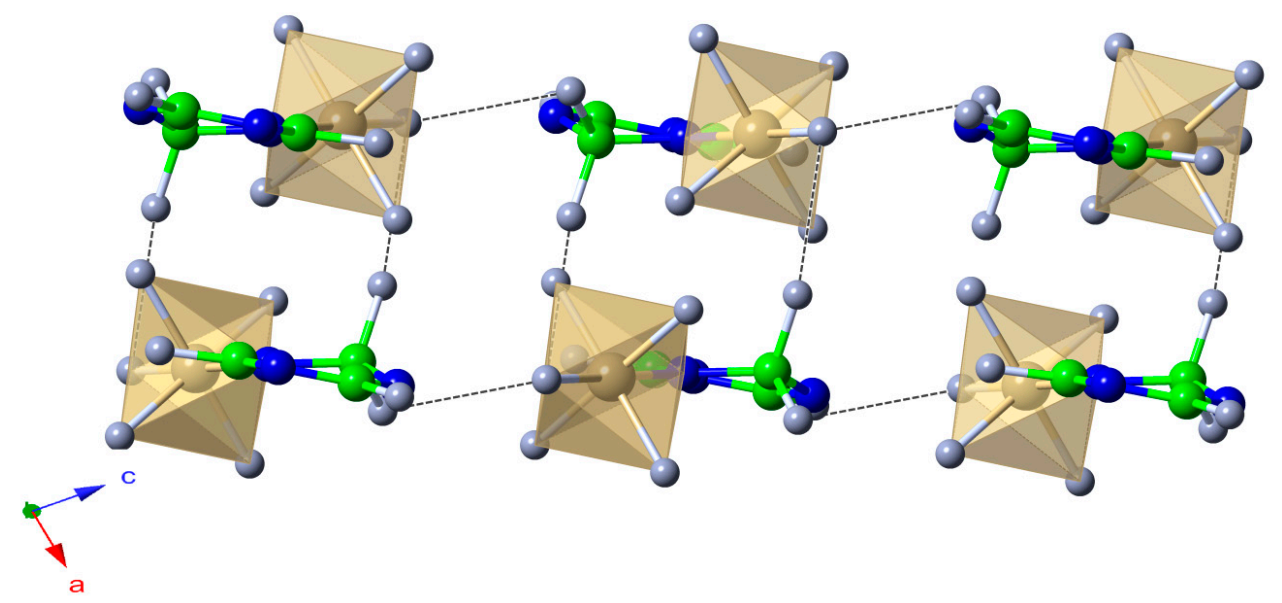

(a)

Figure 5. Cont. 


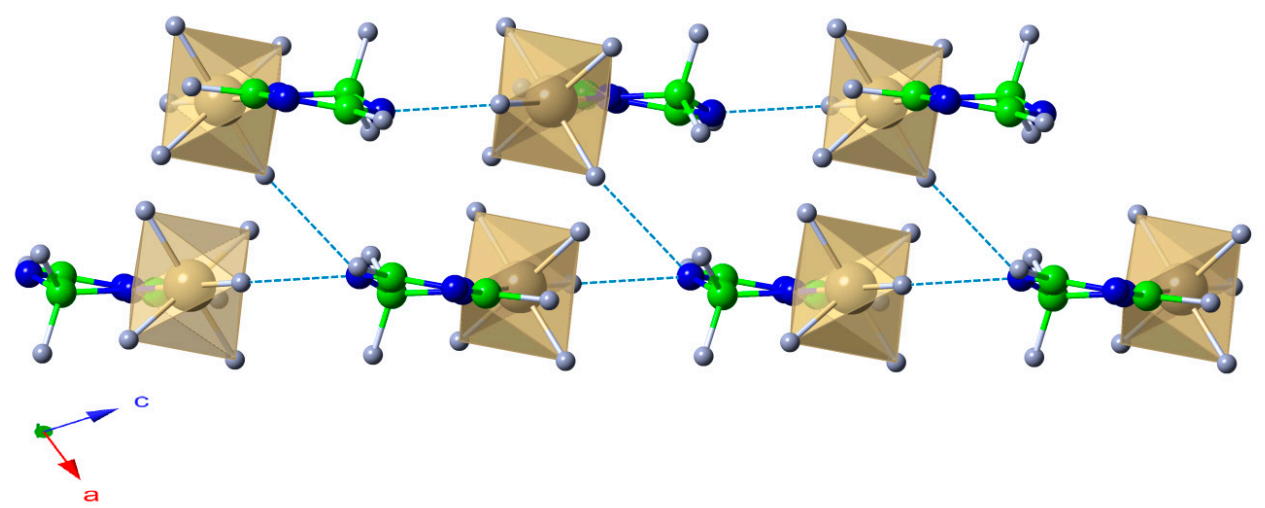

(b)

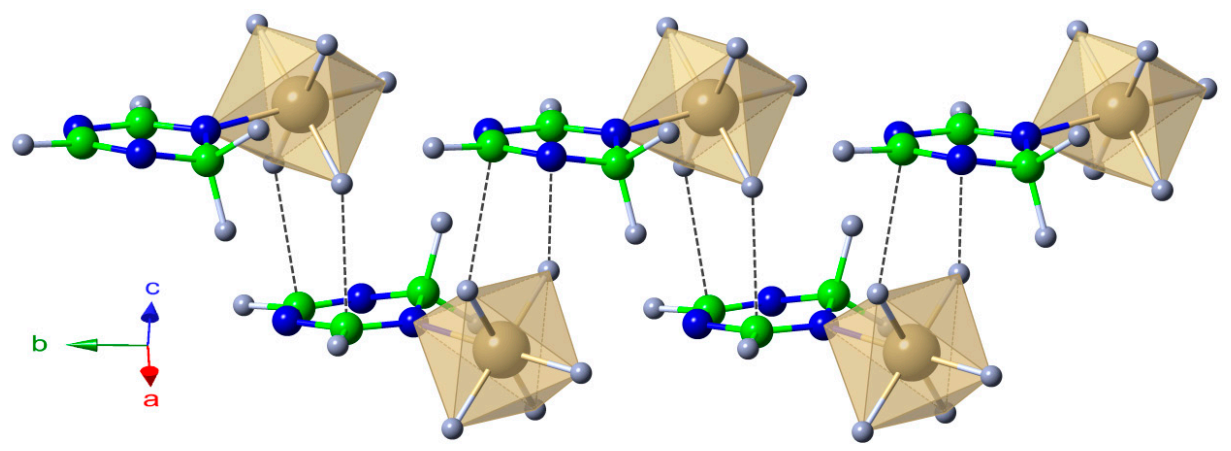

(c)

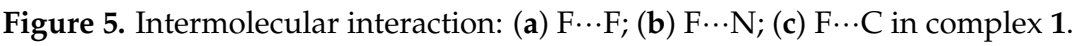

\section{Conclusions}

The complex, $\mathrm{C}_{3} \mathrm{~F}_{4} \mathrm{~N}_{3} \mathrm{OsF}_{5}$, was obtained unexpectedly from the reaction mixture of $\mathrm{OsF}_{6}$, $\mathrm{SO}_{2} \mathrm{ClF}, \mathrm{SbF}_{5}$ and $\mathrm{C}_{3} \mathrm{~N}_{3} \mathrm{~F}_{3}$. The structure of the title compound was determined by single x-ray diffraction analysis. The complex composed of a monodentate triazine anion $\left(\mathrm{C}_{3} \mathrm{~N}_{3} \mathrm{~F}_{4}{ }^{-}\right)$bonded to pentafluoroosmium(VI) cation in an octahedral geometry. The crystal lattice displays many intermolecular interactions, $\mathrm{F} \cdots \mathrm{F}, \mathrm{F} \cdots \mathrm{N}$ and $\mathrm{F} \cdots \mathrm{C}$, leading to three dimensional structure.

Acknowledgments: Monther A. Khanfar thanks the Deutsche Forschungsgemeinschaft (DFG) for a stipend (Ref: SE 293/42-1).

Author Contributions: Monther A. Khanfar and Hashem Shorafa conceived and designed the experiments; Monther A. Khanfar performed the syntheses and prepared the single-crystal samples; Konrad Seppelt performed single-crystal analysis, Basem F. Ali helped in the data analysis; Basem F. Ali and Monther A. Khanfar wrote the paper.

Conflicts of Interest: The authors declare no conflict of interest.

\section{References}

1. Khanfar, M.A.; Seppelt, K. Fluorinated benzene cations. J. Fluor. Chem. 2015, 179, 193-197. [CrossRef]

2. Shorafa, H.; Mollenhauer, D.; Paulus, B.; Seppelt, K. The two structures of the hexafluorobenzene radical cation $\mathrm{C}_{6} \mathrm{~F}_{6}{ }^{+}$. Angew. Chem. Int. Ed. 2009, 48, 5845-5847. [CrossRef] [PubMed]

3. Chen, X.; Wang, X.; Sui, Y.; Li, Y.; Ma, J.; Zuo, J.; Wang, X. Synthesis, characterization, and structures of a persistent aniline radical cation. Angew. Chem. Int. Ed. 2012, 51, 11878-11881. [CrossRef] [PubMed]

4. Marchetti, F.; Pinzino, C.; Zacchini, S.; Pampaloni, G. Long-Lived radical cations of monocyclic arenes at room temperature obtained by $\mathrm{nbf}_{5}$ acting as an oxidizing agent and counterion precursor. Angew. Chem. Int. Ed. 2010, 49, 5268-5272. [CrossRef] [PubMed] 
5. Marchetti, F.; Pampaloni, G.; Pinzino, C. Room-temperature long-lived $\left[\mathrm{Nb}_{2} \mathrm{~F}_{11}\right]^{-}$salts of radical cations of simple arenes: EPR, UV-Vis and DFT results. J. Organomet. Chem. 2011, 696, 1294-1300. [CrossRef]

6. Mallow, O.; Khanfar, M.A.; Malischewski, M.; Finke, P.; Hesse, M.; Lork, E.; Augenstein, T.; Breher, F.; Harmer, J.R.; Vasilieva, N.V. Diaryldichalcogenide radical cations. Chem. Sci. 2015, 6, 497-504. [CrossRef] [PubMed]

7. Tjahjanto, R.T.; Peintinger, M.F.; Bredow, T.; Beck, J. The Reactions of Thianthrene and selenanthrene with alcl $_{3}$ : coordination complexes, radical ions, and investigations on the unique triple-decker molecule (Thianthrene) ${ }_{3}{ }^{2+}$. Eur. J. Inorg. Chem. 2012, 3625-3635. [CrossRef]

8. Poleschner, H.; Seppelt, K. $\mathrm{XeF}_{2}$ /Fluoride acceptors as versatile one-electron oxidants. Angew. Chem. Int. Ed. 2013, 52, 12838-12842. [CrossRef] [PubMed]

9. Spurg, A.; Schnakenburg, G.; Waldvogel, S.R. Oxidative coupling of diaryldisulfides by $\mathrm{MoCl}_{5}$ to thianthrenes. Chem. Eur. J. 2009, 15, 13313-13317. [CrossRef] [PubMed]

10. Berger, R.; Resnati, G.; Metrangolo, P.; Weber, E.; Hulliger, J. Organic fluorine compounds: A great opportunity for enhanced materials properties. Chem. Soc. Rev. 2011, 40, 3496-3508. [CrossRef] [PubMed]

11. Merkel, L.; Budisa, N. Organic fluorine as a polypeptide building element: In vivo expression of fluorinated peptides, proteins and proteomes. Org. Biomol. Chem. 2012, 10, 7241-7261. [CrossRef] [PubMed]

12. Vincent, J.-M. Recent advances of fluorous chemistry in material sciences. Chem. Commun. 2012, 48, 11382-11391. [CrossRef] [PubMed]

13. Wang, C.; Danovich, D.; Mo, Y.; Shaik, S. On the nature of the halogen bond. J. Chem. Theory Comput. 2014, 10, 3726-3737. [CrossRef] [PubMed]

14. Mukherjee, A.; Tothadi, S.; Desiraju, G.R. halogen bonds in crystal engineering: like hydrogen bonds yet different. Acc. Chem. Res. 2014, 47, 2514-2524. [CrossRef] [PubMed]

15. Rybalova, T.; Bagryanskaya, I.Y. C-F $\cdots \pi, F \cdots H$, and F $\cdots$ F intermolecular interactions and F-Aggregation: Role in crystal engineering of fluoroorganic compounds. J. Struct. Chem. 2009, 50, 741-753. [CrossRef]

16. Osuna, R.M.; Hernández, V.; Navarrete, J.T.L.; D'Oria, E.; Novoa, J.J. Theoretical evaluation of the nature and strength of the F...F intermolecular interactions present in fluorinated hydrocarbons. Theor. Chem. Acc. 2010, 128, 541-553. [CrossRef]

17. Espallargas, G.M.; Brammer, L.; Sherwood, P. Designing intermolecular interactions between halogenated peripheries of inorganic and organic molecules: electrostatically directed $\mathrm{M}-\mathrm{X} \cdots \mathrm{X}^{\prime}-\mathrm{C}$ halogen bonds. Angew. Chem. Int. Ed. 2006, 45, 435-440. [CrossRef] [PubMed]

18. Espallargas, G.M.; Zordan, F.; Marín, A.L.; Adams, H.; Shankland, K.; van de Streek, J.; Brammer, L. Rational modification of the hierarchy of intermolecular interactions in molecular crystal structures by using tunable halogen bonds. Chem. Eur. J. 2009, 15, 7554-7568. [CrossRef] [PubMed]

19. Bui, T.T.T.; Dahaoui, S.; Lecomte, C.; Desiraju, G.R.; Espinosa, E. The Nature of Halogen $\cdots$ Halogen interactions: A model derived from experimental charge-density analysis. Angew. Chem. Int. Ed. 2009, 48, 3838-3841. [CrossRef] [PubMed]

20. Reddy, V.P.; Bellew, D.R.; Prakash, G.K.S. A convenient preparation of sulfuryl chloride fluoride. J. Fluor. Chem. 1992, 56, 195-197. [CrossRef]

21. Drews, T.; Supeł, J.; Hagenbach, A.; Seppelt, K. Solid state molecular structures of transition metal hexafluorides. Inorg. Chem. 2006, 45, 3782-3788. [CrossRef] [PubMed]

22. Veith, M.; Bärnighausen, H. Die Kristall- und Molekülstruktur von Bis(trimethylsilyl)diimin. Acta Cryst. 1974, 30, 1806-1813. [CrossRef]

23. Sheldrich, G.M. A short history of SHELX. Acta Cryst. 2008, 64, 112-122. [CrossRef] [PubMed]

24. Sheldrich, G.M. Crystal structure refinement with SHELXL. Acta Cryst. 2015, 71, 3-8.

25. Chambers, R.D.; Philpot, P.D.; Russell, P.L. Reactions involving fluoride ion. Part 14. Anionic $\sigma$-complexes from polyfluorinated s-triazines. J. Chem. Soc. Perkin Trans. 1977, 1, 1605-1608. [CrossRef]

26. Kingston, M.; Chen, S.-J.; Lork, E.; Mews, R. Anionic triazine systems. Dalton Trans. 2004, 9, $1400-1404$. [CrossRef] [PubMed]

27. Seppelt, K. Molecular Hexafluorides. Chem. Rev. 2015, 115, 1296-1306. [CrossRef] [PubMed] 
28. Craciun, R.; Picone, D.; Long, R.T.; Li, S.; Dixon, D.A.; Peterson, K.A.; Christe, K.O. Third row transition metal hexafluorides, extraordinary oxidizers, and lewis acids: electron affinities, fluoride affinities, and heats of formation of $\mathrm{WF}_{6}, \mathrm{ReF}_{6}, \mathrm{OsF}_{6}, \mathrm{IrF}_{6}, \mathrm{PtF}_{6}$, and $\mathrm{AuF}_{6}$. Inorg. Chem. 2010, 49, 1056-1070. [CrossRef] [PubMed]

29. Martínez Casado, F.J.; Ramos Riesco, M.; Redondo, M.I.; Choquesillo-Lazarte, D.; López-Andrés, S.; Rodríguez Cheda, J.A. Anhydrous lithium acetate polymorphs and its hydrates: Three-dimensional coordination polymers. Cryst. Growth Des. 2011, 11, 1021-1032. [CrossRef] 